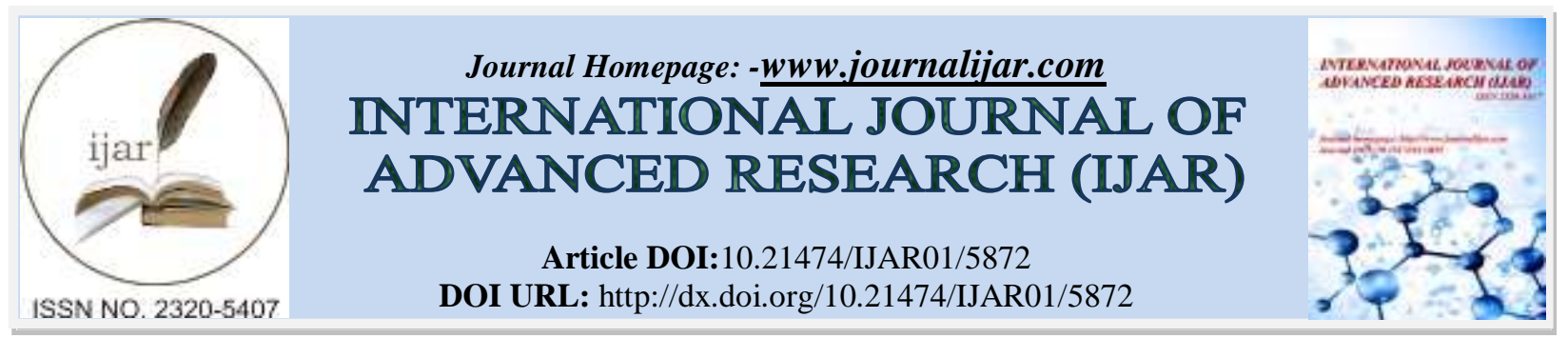

RESEARCH ARTICLE

\title{
ON A COLLECTION OF FRESHWATER ROTIFERS UNDER FAMILY BRACHIONIDAE (EUROTATORIA: MONOGONONTA) FROM NUNGSHANGKONG RIVER, UKHRUL DISTRICT, MANIPUR, INDIA.
}

Ersilia Jajo $^{1}$ and Tongbram Rebanta Singh ${ }^{2}$.

1. Department of Zoology, Pettigrew College, Ukhrul, Manipur, India.

2. Department of Zoology, Jiri College, Jiribam, Manipur, India.

\section{Manuscript Info}

Manuscript History

Received: 15 September 2017

Final Accepted: 17 October 2017

Published: November 2017

Key words:-

Freshwater, rotifer, Brachionidae, Manipur, India.

\section{Abstract}

Taxonomic descriptions of 12 rotifer species belonging to 5 genera under family Brachionidae (Eurotatoria:Monogononta), collected from 5 study sites in Ukhrul district of Manipur in North-East India are reported. The genera-wise species composition was as follows: Brachionus (8 spp.), Keratella (1 sp.), Anuraeopsis (1), Platyias (1) and Plationus (1). Out of the 12 species, B. falcatus was the most abundant species, occurring in all the eight study sites. B. angularis, $B$. calyciflorus, B. quadridentatus and P. plationus occurred in 3 sites, while Keratella tropica occurred in 4 sites, Platyias quadricornis in 2 sites and Brachionus rubens in 3 sites. The least abundant species was Brachionus urceolaris occurring in only 1 site, followed by Brachionus mirabilis occurring in 2 sites.

Copy Right, IJAR, 2017,. All rights reserved.

\section{Introduction:-}

Rotifers are a group of pseudocoelomate microscopic animals, which occur in an endless variety of aquatic and semi-aquatic habitats including the limnetic and deepest regions of largest lakes and smallest puddles (Pennak, 1978). In India, taxonomic studies on the rotifers began with the work of Anderson (1889). Later, contributions by Edmundson and Hutchinson (1934), Sewell (1934, 1935), Ahlstrom (1940), (Arora, 1962), Nayar (1965), Vasisht and Battish (1971), Sharma (1996, 1999), Sudzuki (1989), Arora\&Mehra (2003) and others had greatly increased our knowledge on freshwater rotifers occurring in different parts of the country.

There are meagre reports on rotifers collected from freshwater bodies in different districts of Manipur except that of Ersilia and Shashikumar (2005) and Ersilia (2008). Hence, the present work is taken up to contribute to the knowledge on freshwater rotifers in Manipur, India.

\section{Materials \& methods:-}

Materials for the present study were collected during the period from December 2015 to October 2016 from five collection sites, viz. (1) Nungshongkong River in Ukhrul District(Site I), (2) Paddy cum fish culture at Nungshangkong River, Ukhrul District(Site II), (3) Paddy cum fish culture at Nungshangkong River, Ukhrul District(Site III), (4) Private fish farm near Nungshangkong River, Ukhrul District (Site IV), (5) ) Private fish farm near Nungshangkong River, Ukhrul District. The zooplankton collection was done at monthly intervals. Samples were taken during morning, mid-day and evening. 
Plankton samples were collected following the methods described by Edmondson (1959), Michael (1984) and APHA (1992) using plankton nets made of bolting silk cloth no. 25 of mesh size 55 microns. The collected samples were either fixed in the field or were transferred unaltered (preferably cooled) to the laboratory for examination. Identification of loricate rotifers was done by observing the lorica morphology of contracted specimens using the material fixed and preserved in 4 per cent formaldehyde. Fixing of rotifer specimens in a non-contracted form was done by theHot water treatment method of Edmondson (1959), as reported by Battish (1992). Image capture of live and preserved samples, and measurements were done using a Motic computerized digital Projection Microscope System with inbuilt CCD camera and Motic 2000 image capture software. Identification and description of species was done following Edmondson (1959), Patil and Gouder (1989), Battish (1992), Segers (1995), Sharma (1999). Segers (2002) was followed regarding classification and nomenclature of Phylum Rotifera.

\section{Results and discussions:-}

Altogether 12 rotifer species belonging to 5 genera under the family Brachionidae (Eurotatoria:Monogononta:Pseudotrocha:Ploima) were identified and described. Out of the 12 species, 8 belong to genus Brachionus, while 1 species each belongs to the genera Keratella, Anuraeopsis, Platyias and Plationus.

\section{Description of species:-}

Brachionus angularis Gosse, 1851 (Plate 1, Fig. 1)

Brachionus angularis Gosse, 1851, p. 203.

\section{Materials: Sites II, III and IV.}

Description:Lorica oval, slightly stippled; Anterior dorsal margin with two short median spines with U- shaped notch in between; lateral and intermediate spines absent; Foot opening with U- shaped aperture and two short bluntly pointed protuberances in the ventral plate, relatively close together and convergent.

Size: Total length $125-127.1 \mu \mathrm{m} ; \max ^{\mathrm{m}}$ width $102-107.7 \mu \mathrm{m}$.

Occurrence: India: West Bengal, Andhra Pradesh, Assam, Orissa, Maharashtra, Madhya Pradesh, Delhi, Kashmir, Punjab, Haryana, and Chandigarh. Elsewhere: Cosmopolitan.

Brachionus urceolaris O. F. Muller, 1773 (Plate 1, Fig.2a \& 2b)

Brachionus urceolaris Muller, 1773, p. 131

\section{Materials: Site II}

Description: Lorica moderately oval with rounded posterior. Anterior dorsal margin with six acute spines; median spines longest, laterals and intermediates of same length; Occipital spines four. Foot opening almost rectangular dorsally but semi-circular ventrally.

Size: Total length 66- 69.4 $\mu \mathrm{m}$; maximum width 73-79.0 $\mu \mathrm{m}$.

Occurrence: India: Madhya Pradesh and Punjab. Elsewhere: Cosmopolitan.

Brachionus plicatilis O. F. Muller, 1786 (Plate 1, Fig. 3)

Brachionus plicatilis Muller, 1786, p. 344, Pl. L, figs. 128.

Materials: Sites II, III and IV.

Description: Lorica oval and lightly stippled; anterior dorsal margin with six, short broad-based and saw-toothed occipital spines of almost equal lengths; Posterior spines absent.

Size: Total length 168 - $172 \mu \mathrm{m}$; width 129-132 $\mu \mathrm{m}$.

Occurrence: India: West Bengal, Assam, Rajasthan, Punjab, and Ladakh. Elsewhere: Cosmopolitan.

Brachionus calyciflorus Pallas, 1766 (Plate 1, Fig. 4)

Brachionus calyciflorus Pallas, 1766, Hagae Comitum., p. 93.

Materials: Sites II, III and IV.

Lorica oval, not separated into dorsal and ventral plates. Occipital margin with four broad-based spines of varying lengths.Medians longer than laterals. Ventral margin rather flexible, with a V- shaped shallow notch. Posterior spines present.

Size: Total length $178-182 \mu \mathrm{m}$; maximum width $158-161.7 \mu \mathrm{m}$. 
Occurrence: India: West Bengal, Orissa, Andhra Pradesh, Madhya Pradesh, and Punjab. Elsewhere: Cosmopolitan.

Brachionus mirabilis Daday, 1897 (Plate 1, Fig. 5)

Brachionus mirabilis Daday, 1897, p. 140, fig. 8.

Materials: Sites II, III and IV.

Description: Lorica firm and stippled. Occipital margin with six spines; medians longest and curved outwards. Ventral plate terminates into two long posterior spines. Foot-opening situated between the bases of ventral spines and surrounded by a sheath.

Size: Total length 365-369.9 $\mu \mathrm{m}$; maximum width 162-166 $\mu \mathrm{m}$.

Occurrence: India: West Bengal, Assam, and Orissa. Elsewhere: Tropics.

Brachionus falcatus Zacharias, 1898 (Plate 1, Fig.6a \& 6b)

Brachionus falcatus Zacharias, 1898, p.45, taf.1v, fig.4.

Materials: Sites I, II, III, IV and V.

Description: Lorica firm, compressed and lightly stippled. Occipital margin with two long intermediates, two very short laterals and two equally short laterals. Posterior spines long, outwardly curved and coming nearer basally.

Size: Total length 371-380 $\mu \mathrm{m}$; maximum width 110-115 $\mu \mathrm{m}$.

Occurrence:India: West Bengal, Assam, Orissa, Bihar, Andhra Pradesh, Madhya Pradesh, Gujarat, Rajasthan, Kerala, Punjab and Haryana. Elsewhere: Pantropical and Subtropical.

Brachionus quadridentatus Hermann, 1783 (Plate 1, Fig. 7)

Brachionus quadridentatus Hermann, 1783, p.47, pl. 11, fig.9.

Materials: Sites II, III and IV.

Description: Lorica stippled, wider than long. Anterior dorsal margin with six short spines; unequal in length.Medians longest and curved downwards; laterals longer than intermediates. Narrow V- shaped sinus between the basal regions of median spines; Posterolateral spines of almost equal length.Foot retractile. Size: Total length 222-226 $\mu \mathrm{m}$; maximum width 140-142.7 $\mu \mathrm{m}$.

Occurrence: India: West Bengal Assam, Orissa, Andhra Pradesh, Madhya Pradesh, Kerala, Rajasthan, Punjab and Kashmir. Elsewhere Cosmopolitan.

Brachionus rubens Ehrenberg, 1838 (Plate 1, Fig. 8)

Brachionus rubens Ehrenberg, 1838, p.513, pl.LX111, fig.4.

Materials: Sites II, III and VI.

Description:Lorica goblet or oval-shaped. Anterior margin with six occipital spines; median and intermediate, occipital spines with a narrow anterior part and a broad base. Foot opening with a rectangular aperture dorsally and a larger oval aperture ventrally. Size: Total length 157.3-160.7 $\mu \mathrm{m}$; maximum width 137-140 $\mu \mathrm{m}$. Occurrence: India: West Bengal, Assam, Orissa, Punjab Haryana and Rajasthan. Elsewhere: Cosmopolitan.

Keratella tropica (Apstein, 1907) (Plate 1, Fig. 9)

Aureavalga f. tropica Apstein, 1907, p. 210, fig. F.

Keratella tropica (Apstein) :Berzins, 1955, p. 554.

Materials: Sites II, III, IV and V.

Description: Lorica elongated, oval with six occipital spines; medians longest, pointed and curved outwardly. Two posterior spines of unequal lengths; the right spine much longer.

Size: Total length 170.4-175.6.1 $\mu \mathrm{m} ; \max ^{\mathrm{m}}$ width 60.5-64.6 $\mu \mathrm{m}$.

Occurrence: India: West Bengal, Assam, Bihar, Orissa, Andhra Pradesh, Madhya Pradesh, Kerala, Gujarat, Rajasthan, Punjab, Haryana, Kashmir and Ladakh. Elsewhere : Tropics and Subtropics.

Anuraeopsis fissa (Gosse, 1851) (Plate 1, Fig. 10)

Anureafissa Gosse, 1851, p.202; Anureafissa (Gosse) :Harring, 1913 b, p.13.

Anuraeopsis fissa fissa (Gosse) :Berzins, 1962, p.35. 
Materials: Sites I III and VII.

Description: Lorica thin, stippled and obtusely pointed posteriorly; dorsal margin with a shallow notch in the middle. Ventral plate projecting beyond dorsal plate anteriorly. Foot absent.

Size: Total length 90.6- $92.7 \mu \mathrm{m}$; maximum width 40.7- $45.0 \mu \mathrm{m}$.

Occurrence: India: West Bengal, Assam, Orissa, Kerala, Rajasthan, Gujarat, Punjab, Chandigarh (U.T.) Haryana. Elsewhere: Cosmopolitan.

Platyias quadricornis (Ehrenberg, 1832) (Plate 1, Fig. 11)

Platyias quadricornis (Ehrenberg)

Materials: Sites II and III.

Description: Lorica almost circular, tuberculated; Two stout median spines, bluntly rounded or truncated tips. Posterior spines two.

Size: Total length 97.5-101.3 $\mu \mathrm{m}$; maximum width 90.8- 95.3 $\mu \mathrm{m}$.

Occurrence: India: West Bengal, Assam, Orissa, Andhra Pradesh, Kerala, Rajasthan, Punjab, Haryana, Kashmir, Ladakh. Elsewhere: Cosmopolitan.

Plationus patulus (Muller, 1786) (Plate 1, Fig. 12)

Brachionus patulas Muller, 1786, p. 361.

Platyias patulus (Muller): Ahlstrom, 1940, p. 175, pl. 19, figs. 1-4.

Materials: Sites II, III, and IV.

Description: Lorica firm sub-rectangular. Occipital margin with 10 pronounced spines; Posterior spines short and stout, unequal in size; Foot-opening flanked by two short spines.

Size: Total length 140-149.1 $\mu \mathrm{m} ; \max ^{\mathrm{m}}$ width 102.0-105.1 $\mu \mathrm{m}$.

Occurrence: India: Orissa, Andhra Pradesh, Gujarat, Tamil Nadu, Kerala, Rajasthan, Punjab and Kashmir. Elsewhere: Cosmopolitan.

The genera-wise species composition was Brachionus (8 spp.), Keratella (1 sp.), Anuraeopsis (1), Platyias (1) and Plationus (1). Out of the 12 species, B. falcatus was the most abundant species, occurring in all the eight study sites. B. angularis, B. calyciflorus, B. quadridentatus and P. plationus occurred in 7 sites, while Keratella tropica occurred in 6 sites, Platyias quadricornis in 5 and Brachionus rubens in 4 sites. The least abundant species was Brachionus urceolaris occurring in only 1 site, followed by Brachionus mirabilis occurring in 2 sites.

Plate 1

Freshwater rotifers under family Brachionidae from Manipur, India 


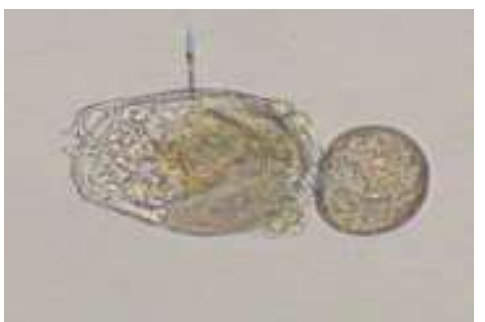

Fig. 1. Brachionus angularis.

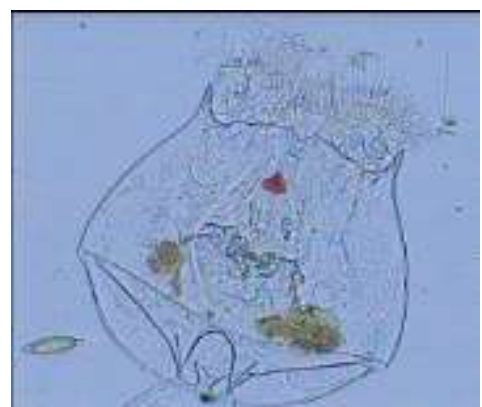

Fig. 2a. Brachionus urceolaris

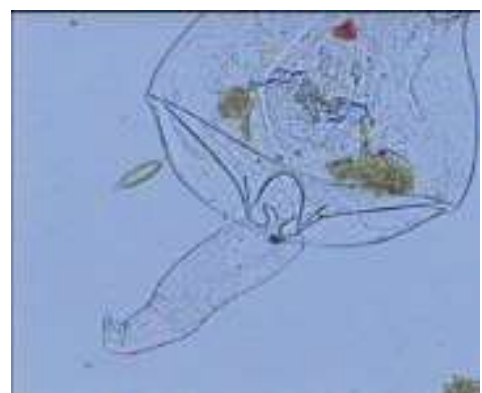

Fig. 2b. Brachionus urceolaris

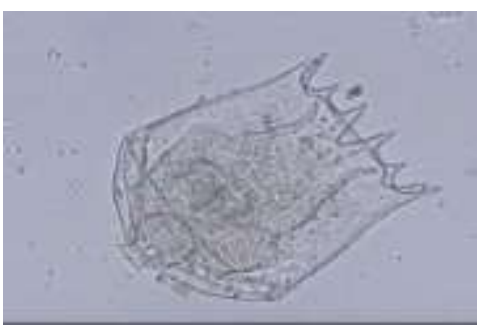

Fig.3. Brachionus plicatilis

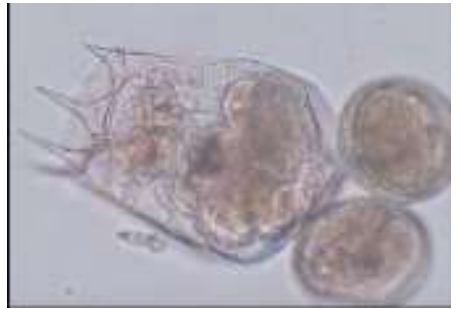

Fig. 4. Brachionus calyciflorus

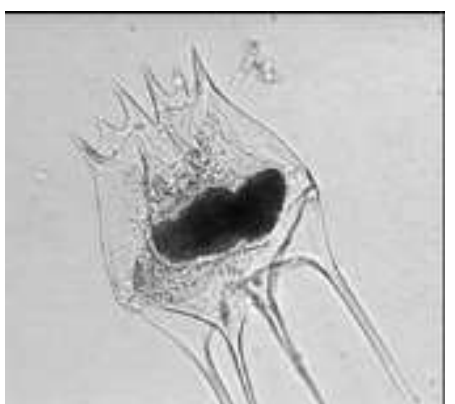

Fig. 5. Brachionus mirabilis

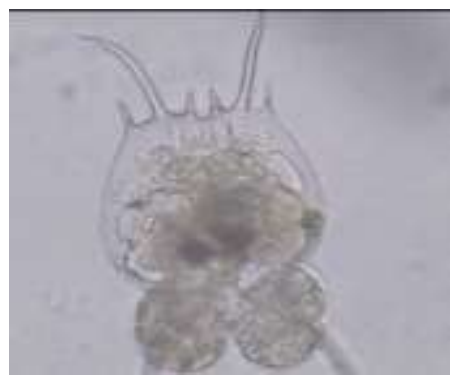

Fig. 6a.Brachionus falcatus

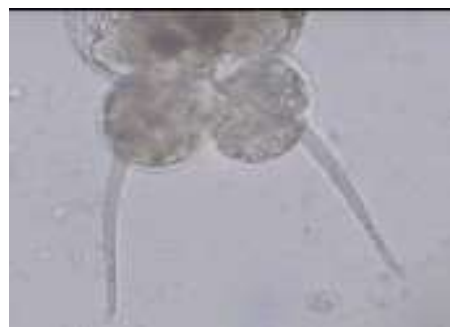

Fig. 6b. Brachionus falcatus 


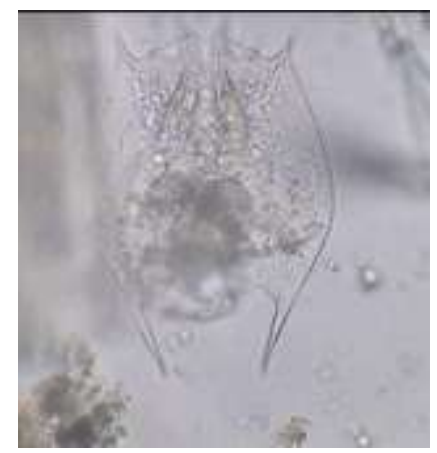

Fig. 7. Brachionus quadridentatus

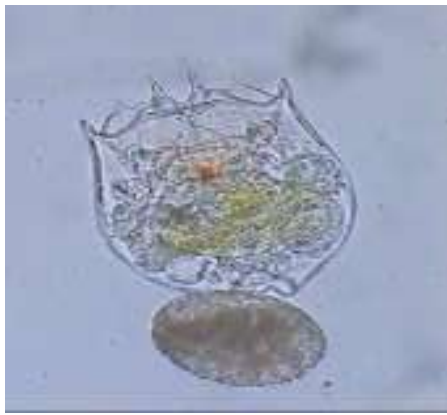

\section{Fig. 8. Brachionus rubens}

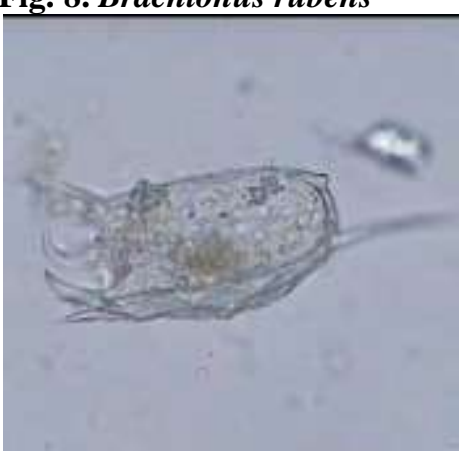

Fig.9.Keratella tropica

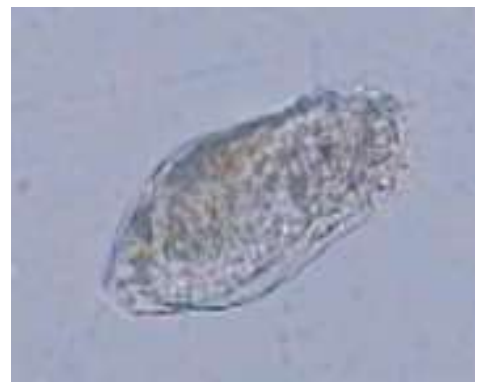

Fig.10. Anuraeopsis fissa

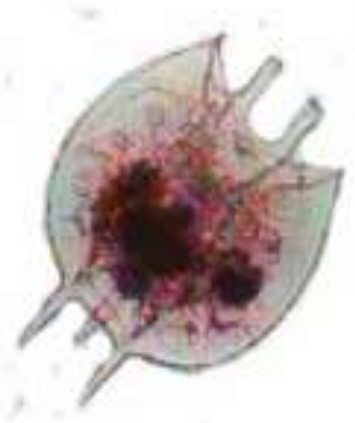

Fig.11. Platyias quadricornis

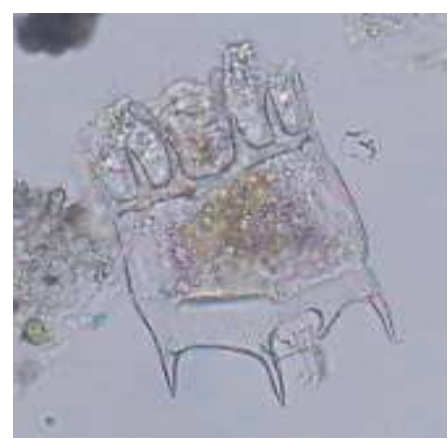

Fig.12.Plationus patulus

\section{Acknowledgment:-}

The author is thankful to University Grants Commission, NERO, Guwahaty for providing financial assistance to do the present minor research work. Gratitude is acknowledged to Tongbram Rebanta singh, assistant professor, Dept. of Zoology, JiriCollege,Jiribam for valuable suggestions.

\section{References:-}

1. Anderson, H. H., 1889: Notes on Indian Rotifers. J. Asiatic Soc. Bengal, Calcutta, 58: 345-358.

2. APHA, 1992: Standard Methods for the Examination of water and Wastewaters. $18^{\text {th }}$ Edition, American Public Health Association, Washington D. C. pp. 874.

3. Arora, H. C., 1962: Studies on Indian Rotifera Part I On a small collection of illoricateRotifera from Nagpur, India, with notes on their bionomics. J. Zool. Soc. India, 14: 33-44.

4. Arora, J. and Mehra, N. K., 2003: Species diversity of planktonic and epiphytic rotifers in the backwaters of the Delhi segment of the Yamuna River, with remarks on new records from India. Zool. Stud. 42 (2): 239-247.

5. Battish, S. K., 1992: Freshwater Zooplankton of India. Oxford \& IBH Publishing Co., New Delhi. 233 pp. 
6. Edmondson, W. T., 1959: Rotifera. In Freshwater Biology (Eds. H.B. Ward and G.C. Whipple) $2^{\text {nd }}$ Ed., John Wiley and Sons, New York,Pp. 1-1248.

7. Edmondson, W. T. and Hutchinson, G. E., 1934: Report on Rotatoria. Yale North India Expedition. Mem. Conn. Acad. Arts. Sci., 10:153-186.

8. ErsiliaJajo and Singh O.S. (2005): Preliminary studies on the Rotifer Fauna of Manipur. Abstracts of Papers NASFAB-05: BC31.

9. Khan, R. A., 2003: Rotifera. In Faunal Diversity in Freshwater Zooplankton in Freshwater Wetlands of Southeastern West Bengal. Rec. Zool. Surv. India. Occ. Paper No.24. Pp. 8 - 48.

10. Mahajan, C. L., 1981: Zooplankton as indicator for assessment of water pollution. Cent. Bd. Prev. Cent. Poll. Osmania University, Hyderabad: 135-148.

11. Michael, P., 1984: Ecological Methods for Field and Laboratory Investigations, Tata McGraw-Hill Publishing Co. Ltd., New Delhi, xii, 404 pp.

12. Nayar, C. K. G, 1965: Taxonomic notes on the Indian species of Keratella(Rotifera) Hydrobiologia, 26 (3-4): 457-461.

13. Patil, C.S. and Gouder, B.Y.M., 1982a: New records of illoricate rotifers from India. Curr. Sci. 52(11): 577578.

14. Pennak, R.W., 1978: Freshwater Invertebrates of the United States. $2^{\text {nd }}$ Ed. John Wiley \& Sons., New York, $803 \mathrm{pp}$.

15. Segers H., 2002: The nomenclature of the Rotifer: annotated checklist of valid family-and genus-group names. Jour. Of. Nat. Hist. 36, 631-640.

16. Sewell, R.B.S., 1934: Fauna of Salt lakes, Calcutta. Rec. Ind. Mus., 36: 61-80.

17. Sharma, B. K., 1996: Biodiversity of freshwater Rotifera in India - a status report. Proceedings of theZoological Society, Calcutta 49: 73-85.

18. Sharma, B. K., 1999: Freshwater Rotifers (Rotifera: Eurotatoria). Zool. Surv. India, State Fauna Series 3, Fauna of West Bengal, Part 11: 341 - 468.

19. Sudzuki, M., 1989: Rotifera from the Oriental region and their characteristics, Special issue, Cent. Ann. Nihon Daigaku, $3:$ 301-343.

20. Vashist, H. S. \&Battish, S. K.,1971: The Rotifer fauna of North India: Brachionus. Res.Bulletin N.S.), Punjab University, 22: 189-122. 